\title{
HUBUNGAN TINGKAT PENGETAHUAN PERAWAT TENTANG KEMOTERAPI DENGAN TINDAKAN PEMBERIAN KEMOTERAPI PADA PASIEN KANKER PARU
}

\author{
Nining Fitrianingsih \\ Sekolah Tinggi Ilmu Kesehatan Wijaya Husada Bogor \\ Email: nienk1406@yahoo.com
}

\begin{abstract}
ABSTRAK
Latar Belakang: Kemoterapi merupakan salah satu cara pengobatan kanker dengan memberikan obat atau zat yang berkhasiat membunuh sel kanker. Dalam tindakan medis, perawat harus memiliki pengetahuan tentang prosedur pemberian obat kemoterapi karena pemberian kemoterapi yang dilakukan oleh perawat rentan terkena pada kulit atau mata pada saat melakukan tindakan. Tujuan Penelitian: mengetahui hubungan tingkat pengetahuan perawat tentang kemoterapi dengan tindakan pemberian kemoterapi pada pasien kanker paru. Metode: Desain penelitian yang digunakan ialah analisis korelasional dengan pendekatan cross sectional. Populasi yang diteliti adalah perawat berjumlah 46 dengan teknik pengambilan sampel total sampling. Instrumen penelitian berupa uesioner dan lembar observasi. Analisis data secara univariat dan divariat. Hasil: hasil penelitian menunjukkan nilai uji statistik chi square dengan $p$ value $=0,001(\leq 0,05)$, hal ini berarti ada hubungan antara tingkat pengetahuan perawat tentang kemoterapi dengan tindakan pemberian kemoterapi pada pasien kanker paru. Diskusi: seseorang yang mempunyai tingkat pengetahuan, pengalaman kerja yang banyak, serta diikuti bertambahnya usia akan memberikan pelayanan/perawatan dalam pemberian kemoterapi yang lebih baik hasilnya. Simpulan: perawat yang memiliki pengetahuan yang baik tentang kemoterapi akan memberikan tindakan kemoterapi yang sesuai dengan prosedur.
\end{abstract}

Kata Kunci: Pengetahuan, kemoterapi, kanker paru.

\section{THE CORRELATION BETWEEN KNOWLEDGE LEVEL OF NURSES ABOUT CHEMOTHERAPHY AND CHEMOTHERAPHY ADMINISTRATION IN LUNG CANCER PATIENTS ABSTRACT}

Background: Chemotherapy is one of the methods in treating cancer by providing efficacious drugs or substances that kill cancer cells. In a medical procedure, nurses must have knowledge of procedures for chemotherapy regimens because the chemotherapy conducted by nurses is susceptible to skin or eyes at the time of the intervention. Objective: To identify the correlation between knowledge level of nurses about chemotheraphy and chemotheraphy administration in lung cancer patients. Methods: This study was correlational analytical with cross sectional approach. Samples were 46 nurses taken using total sampling technique. Questionnaire observation sheet were used as instruments. Data was analyzed with univariate and bivariate. Results: There was a correlation between knowledge level of nurses about chemotherapy and chemotherapy administration, $p$ value $=0.001$ ( $\leq$ 0.05). Discussion: One who has higher level of knowledge, a lot of work experience, and get older will administer better chemotherapy. Conclusions: Nurses with comprehensive knowledge of chemotherapy will administer chemotherapy in accordance with procedure.

Keywords: Knowledge level, Chemotherapy, Lung Cancer 


\section{PENDAHULUAN}

WHO (World Health Organization) tahun 2007 melaporkan bahwa insiden penyakit kanker di dunia mencapai 12 juta penduduk. Di negara maju seperti Amerika Serikat dan Inggris, kematian akibat kanker menduduki peringkat kedua setelah penyakit kardiovaskuler. Salah satu penyakit kanker yang menyebabkan kematian tertinggi di dunia ialah kanker paru (Karen, V., dkk., 2014).

Kanker paru merupakan penyebab utama pada kelompok penyakit akibat keganasan. Kanker paru merupakan penyakit dengan ciri khas adanya pertumbuhan sel yang tidak terkontrol pada jaringan paru-paru. Bila tidak dirawat, pertumbuhan sel ini dapat menyebar ke luar dari paru-paru melalui suatu proses yang disebut metastasis ke jaringan yang terdekat atau bagian tubuh yang lainnya. Gejala paling umum ialah batuk (termasuk batuk darah), berat badan turun, dan sesak napas (Desen, W., 2008).

Penelitian yang dilakukan oleh National Cancer Institute memperkirakan peningkatan jumlah kanker paru-paru akan meningkat dua kali lipat, dari 65.000 pada 2010 menjadi 137.000 pada 2040. Pada awal abad ke20 kanker paru menjadi masalah global. Kanker paru merupakan kanker yang paling sering dijumpai di dunia. Saat ini, 1,2 juta orang meninggal karena kanker paru setiap tahun (Pinheiro, L.C., dkk., 2015).

Penyebab paling umum tingginya prevalensi kanker paru ialah paparan dalam jangka waktu yang lama terhadap asap tembakau, yang menyebabkan 80-90 persen kanker paru. Bukan perokok mencapai angka 10-15 persen dari kasus kanker paru dan kasus ini biasanya disebabkan oleh kombinasi antara faktor genetik, gas radon, asbesitas, dan polusi udara termasuk asap rokok pasif (Wong, J.Y., dkk., 2015).
Banyak cara yang dapat dilakukan untuk terapi kanker. Dalam dunia kesehatan, kanker umumnya diobati dengan tiga jenis (modalitas) pengobatan, yaitu operasi, radioterapi, dan kemoterapi (Somantri, I, 2008).

Kemoterapi merupakan salah satu cara pengobatan kanker dengan memberikan obat atau zat yang berkasiat membunuh sel kanker. Para ahli mengakui bahwa kemoterapi mempunyai kemampuan untuk memperpanjang hidup pasien, meningkatkan kualitas hidup, dan meningkatkan harapan untuk pengobatan jutaan orang yang terkena kanker. Lebih dari separuh penderita kanker mendapatkan tindakan pengobatan dengan kemoterapi dan efeknya bagi banyak penderita sangat efektif (Boucher, J., dkk., 2015).

Pemberian kemoterapi apabila tidak dilaksanakan sesuai prosedur berdampak negatif pada pasien dan juga perawat. Oleh sebab itu, perawat harus memiliki pengetahuan tentang prosedur kemoterapi yang aman, yaitu mulai dari pelaksanaan awal pemberian kemoterapisampai dengan pemakaian alat pelindung diri (APD) yang lengkap berupa sarung tangan khusus untuk kemoterapi, kacamata pelindung, masker, dan pakaian pelindung. Dalam memberikan obat kemoterapi diperlukan ruangan khusus dan pakaian khusus untuk melindungi perawat pada saat pelaksanaan pencampuran obat (Jayanti, 2013).

Pelaksanaan kemoterapi yang direkomendasikan oleh ASCO (American Society of Clinical Oncology)/ ONS (Oncology Nursing Society) tahun 2007, secara umum menjelaskan pelaksanaan pemberian kemoterapi meliputi multi persiapan (tenaga medis, pasien, obat), pelaksanaan atau pengelolaan, monitoring dan evaluasi (Dempsey, 2008). 
Dalam tindakan medis, perawat harus memiliki pengetahuan tentang prosedur pemberian obat kemoterapi. Karena pemberian kemoterapi yang dilakukan oleh perawat rentan terkena pada kulit atau mata pada saat melakukan tindakan (Yanase, dkk., 2014). Eksposur kemoterapi dapat memengaruhi sistem saraf yang akan mengganggu sistem reproduksi dan membawa peningkatan risiko kanker darah di masa depan dan berbahaya untuk kesehatan perawat (Tjay dan Rahardja, 2002).

Standar operasional pemberian kemoterapi pada pasien dengan kanker paru yang ada di Rumah Sakit Paru Dr.M. Goenawan Partowidigdo Cisarua Bogor, yakni meliputi tahap persiapan dan cara pemberian kemoterapi. Tahap persiapan contohnya mempersiapkan data ukuran TB (tinggi badan), BB (berat badan), luas badan, darah lengkap, fungsi ginjal, fungsi liver, gula darah, urine lengkap, EKG, foto thorax AP/lateral, ekokardiografi, dan periksa adanya inform consent, serta obat sitostatika. Sementara itu, cara pemberian kemoterapi salah satu tindakan perawat yakni periksa pasien, jenis obat, dosis obat, jenis cairan, volume cairan, cara pemberian, waktu pemberian dan akhir pemberian, serta memakai proteksi, lakukan prinsip aseptik dan septik (RSPG, 2015).

Berdasarkan data yang didapatkan di Rumah Sakit Paru Dr. M. Goenawan Partowidigdo Cisarua Bogor, jumlah kunjungan pasien kanker paru pada periode bulan Januari sampai dengan Juni 2015 sebanyak 237 pasien, sedangkan tindakan yang dilakukan kemoterapi di tiga (3) ruangan Melati, Anggrek, dan Kaca Piring sebanyak 42 kali tindakan kemoterapi. Berdasarkan studi pendahulun yang dilakukan oleh peneliti di RS Paru Dr. M. Goenawan Partowidigdo Cisarua Bogor melalui wawancara 14 orang perawat diketahui seluruh perawat belum ada yang mendapatkan pelatihan atau workshop mengenai kemoterapi. Sementara itu, dalam melakukan tindakan kemoterapi, SOP belum tersosialisasi kepada seluruh perawat sehingga dalam pelaksanaannya perawat hanya memakai alat pelindung diri seadanya pada saat pemasangan obat kemoterapi. Kurangnya pelatihan pengetahuan dan tindakan mengenai pemberian kemoterapi terhadap pasien dapat mengakibatkan kecelakaan dan keselamatan perawat.

Tujuan penelitian ini untuk mengetahui hubungan tingkat pengetahuan perawat tentang kemoterapi dengan tindakan pemberian kemoterapi di RS Paru Dr. M. Goenawan Partowidigdo Cisarua Bogor.

\section{METODE PENELITIAN}

Desain penelitian ini termasuk penelitian analisis korelasional dengan pendekatan cross sectional (Nursalam, 2009).

Penelitian ini dilakukan di Instalasi Rawat Inap Melati, Anggrek, dan Kaca piring Rumah Sakit Paru Dr.M. Goenawan Cisarua Kab. Bogor, pada tanggal 21-26 Agustus 2015. Populasi dalam penelitian ini ialah semua perawat berjumlah 46 perawat. Pengambilan sampel penelitian ini dilakukan dengan cara atau teknik total sampling.

Alat pengumpulan data dalam penelitian ini adalah kuesioner dan lembar observasi. Kuesioner berisi data karakteristik responden yang meliputi usia, pendidikan terakhir, dan pengalaman bekerja. Untuk variabel pengetahuan perawat tentang kemoterapi, kuesioner berisi 14 pernyataan yang dibuat sendiri oleh peneliti berdasarkan sumber rujukan dari Buku Ajar Onkologi Klinis (Desen W, 2008).

Alat ukur untuk variabel pemberian tindakan kemoterapi berupalembarobservasi berjumlah 19 pernyataan yang diadopsi dari 
SPO yang ada di RSPG Cisarua Bogor.

penelitian ini diuji dengan menggunakan

Uji validitas dilakukan di Rumah Sakit

KuderRichadson-21 (KR-21), didapatkannilai PMI Kota Bogor pada tanggal 14-16 Agustus 2015 terhadap 20 responden dengan menggunakan pearson product moment. Hasil uji validitas dinyatakan valid karena $r$ tabel $>r$ hitung $(0,444)$. Reliabilitas pada kuesioner tingkat pengetahuan dalam 0,964 . Maka kuesioner tingkat pengetahuan dinyatakan reliable. Pengolahan dan analisis data menggunakan komputer. Analisis terdiri dari analisis univariat dan analisa bivariat (Arikunto, 2006).

\section{HASIL PENELITIAN}

Tabel 1.Distribusi frekuensi karakteristik responden berdasarkan usia, pendidikan terakhir, dan pengalaman bekerja di RS Paru Dr. M.Goenawan Partowidigdo Cisarua Bogor tahun 2015

\begin{tabular}{|c|c|c|c|}
\hline No & $\begin{array}{l}\text { Karakteristik } \\
\text { responden }\end{array}$ & Frekuensi & Persentase (\%) \\
\hline \multirow[t]{5}{*}{1.} & Usia & & \\
\hline & 20-29 tahun & 17 & 36,96 \\
\hline & 30-39 tahun & 14 & 30,43 \\
\hline & $\geq 40$ tahun & 15 & 32,61 \\
\hline & Jumlah & 46 & 100 \\
\hline \multirow[t]{4}{*}{2.} & $\begin{array}{l}\text { Pendidikan } \\
\text { terakhir }\end{array}$ & & \\
\hline & $\begin{array}{l}\text { Diploma III } \\
\text { Keperawatan }\end{array}$ & 44 & 95,65 \\
\hline & Ners & 2 & 4,35 \\
\hline & Jumlah & 46 & 100 \\
\hline \multirow[t]{5}{*}{3.} & $\begin{array}{l}\text { Pengalaman } \\
\text { bekerja }\end{array}$ & & \\
\hline & $\leq 2$ tahun & 3 & 6,52 \\
\hline & 3-4 tahun & 12 & 26,09 \\
\hline & $\geq 5$ tahun & 31 & 67,39 \\
\hline & Jumlah & 46 & 100 \\
\hline
\end{tabular}

Tabel 1 menunjukkan karakteristik responden berdasarkan usia bahwa dari 46 responden, sebanyak 17 responden (36,96 persen) berusia 20-29 tahun. Karakteristik responden berdasarkan pendidikan terakhir sebagian besar adalah
Diploma III Keperawatan, yaitu sebanyak 44 (95,65 persen). Karakteristik responden berdasarkan pengalaman bekerja diperoleh data bahwa dari 46 responden sebanyak 31 responden (67,39 persen) berpengalaman $\geq 5$ tahun di RS Paru DR. M. Goenawan Partowidigdo Cisarua Bogor Tahun 2015. 
Tabel 2. Distribusi Frekuensi tingkat pengetahuan perawat tentang Kemoterapi pada Pasien Kanker Paru di RS Paru DR. M. Goenawan Partowidigdo Cisarua Bogor Tahun $2015(n=46)$

\begin{tabular}{ccc}
\hline Tingkat Pengetahuan & Frekuensi & Persentase (\%) \\
\hline Baik & 38 & 82,6 \\
Cukup & 4 & 8,7 \\
Kurang & 4 & 8,7 \\
\hline Total & 46 & 100 \\
\hline
\end{tabular}

Berdasarkan Tabel 2, dari 46 responden, mempunyai pengetahuan baik tentang diketahui sebagian besar responden, kemoterapi. yaitu sebanyak 38 perawat (82,6 persen)

Tabel 3.Distribusi frekuensi pelaksanaan pemberian kemoterapi pada pasien kanker paru di RS Paru DR.M. Goenawan Partowidigdo Cisarua Bogor Tahun $2015(n=46)$

\begin{tabular}{ccc}
\hline $\begin{array}{c}\text { Pelaksanaan } \\
\text { Tindakan Pemberian } \\
\text { Kemoterapi }\end{array}$ & Frekuensi & Persentase (\%) \\
\hline Sesuai prosedur & 31 & 67,4 \\
Tidak sesuai prosedur & 15 & 32,6 \\
\hline Total & 46 & 100 \\
\hline
\end{tabular}

Berdasarkan Tabel 3, dari 46 responden, kemoterapi sesuai prosedur sebanyak diketahui sebagian besar responden 31(67,4 persen). melaksanaan tindakan pemberian

Tabel 4. Hubungan tingkat pengetahuan perawat tentang kemoterapi dengan tindakan pemberian kemoterapi pada pasien kanker paru di RS Paru Dr.M. Goenawan Partowidigdo Cisarua Bogor Tahun 2015 ( $n=46$ )

Tindakan pemberian

\begin{tabular}{|c|c|c|c|c|c|c|}
\hline \multirow{3}{*}{$\begin{array}{c}\text { Tingkat } \\
\text { Pengetahuan }\end{array}$} & \multicolumn{4}{|c|}{ Kemoterapi } & \multirow{3}{*}{ Jml (n) } & \multirow{3}{*}{$\begin{array}{c}\text { p-value } \\
(\%)\end{array}$} \\
\hline & \multicolumn{2}{|c|}{$\begin{array}{l}\text { Sesuai } \\
\text { prosedur }\end{array}$} & \multicolumn{2}{|c|}{$\begin{array}{c}\text { Tidak sesuai } \\
\text { prosedur }\end{array}$} & & \\
\hline & $\mathbf{N}$ & $\%$ & $\mathbf{N}$ & $\%$ & & \\
\hline Baik & 26 & 56,6 & 12 & 26,08 & $\begin{array}{c}38 \\
(82,6 \%)\end{array}$ & \\
\hline Cukup & 4 & 8,7 & 0 & 0 & $\begin{array}{c}4 \\
(8,7 \%)\end{array}$ & \\
\hline Kurang & 1 & 2,17 & 3 & 6,6 & $\begin{array}{c}4 \\
(8,7 \%)\end{array}$ & 0,001 \\
\hline Total & 31 & 67,4 & 15 & 32,6 & $\begin{array}{c}46 \\
(100 \%)\end{array}$ & \\
\hline
\end{tabular}


Hasil analisis hubungan antara tingkat pengetahuan perawat dengan tindakan pemberian kemoterapi, dari 46 responden diketahui sebanyak 26 (56,6 persen) responden mempunyai pengetahuan baik dan tindakan pemberian Kemoterapi sesuai prosedur.

Hasil uji statistik didapatkan nilai $p$ value $=0,001$ ( $p$ value $<0,05)$, ini dapat disimpulkan bahwa "Ada hubungan antara tingkat pengetahuan perawat tentang kemoterapi dan tindakan pemberian kemoterapi pada pasien kanker paru di RS Paru Dr. M. Goenawan Partowidigdo Cisarua Bogor tahun 2015".

\section{DISKUSI}

\section{a. Tingkat Pengetahuan Perawat}

Berdasarkan hasil penelitian dari 46 responden, tingkat pengetahuan perawat tentang kemoterapi sebagian besar memilki pengetahuan baik sebanyak 38 responden (82,6 persen).

Hasil penelitian ini sesuai dengan penelitian yang dilakukan oleh Hidayati (2014) yang berjudul "Hubungan Tingkat Pengetahuan Perawat tentang Kemoterapi dengan Tindakan Pemberian Kemoterapi pada Pasien Kanker Payudara di RSUD Arifin Achmad Pekanbaru". Diperoleh hasil dari 51 responden sebagian besar memiliki pengetahuan baik berjumlah 35 orang $(68,6$ persen), sedangkan yang memilki tingkat pengetahuan sedang berjumlah 14 orang (27,5 persen), dan yang memiliki tingkat pengetahuan kurang hanya 2 orang $(3,9$ persen).

Hasil penelitian ini sesuai dengan teori Notoatmodjo (2007) bahwa pengetahuan itu sendiri dipengaruhi oleh faktor pendidikan formal. Pengetahuan sangat erat hubungannya dengan pendidikan. Diharapkan bahwa dengan pendidikan yang tinggi maka orang tersebut akan semakin luas pula pengetahuannya.

Hal ini sesuai dengan hasil penelitian berdasarkan data karakteristik responden di dapatkan yang memiliki pendidikan terakhir Diploma III Keperawatan berjumlah 44 responden ( 95,65 persen) dan yang memiliki pendidikan terakhir profesi Ners yakni 2 responden (4,35 persen).

Tidak dapat dimungkiri bahwa makin tinggi pendidikan seseorang semakin mudah pula pengetahuan yang dimilikinya. Sebaliknya, jika seseorang tingkat pendidikanya rendah, itu akan menghambat perkembangan sikap seseorang terhadap penerimaan informasi dan nilai-nilai baru yang diperkenalkan (Hidayat, 2009).

Akan tetapi, perlu ditekankan bahwa bukan berarti seseorang yang berpendidikan rendah mutlak berpengetahuan rendah pula. Hal ini mengingat bahwa peningkatan pengetahuan tidak mutlak diperoleh dari pendidikan formal saja, tetapi dapat diperoleh melalui pendidikan nonformal (Samsudin, 2005).

\section{b. Tindakan Pemberian Kemoterapi}

Berdasarkan hasil penelitian yang dilakukan terhadap 46 responden didapatkan hasil bahwa sebagian besar responden memberikan tindakan kemoterapi sesuai prosedur sebanyak 31 responden $(67,4$ persen).

Menurut Nursalam (2009) peran perawat di masa depan harus berkembang seiring dengan perkembangan iptek dan tuntutan kebutuhan masyarakat sehingga perawat dituntut mampu menjawab dan mengantisipasi terhadap dampak dari perubahan. Pelatihan merupakan bagian dari suatu proses pendidikan yang bertujuan untuk meningkatkan kemampuan dan ketrampilan khusus seseorang atau kelompok. Melalui kinerja perawat dapat dapat diketahui bahwa sesungguhnya faktor 
pendidikan dan pengetahuan serta teknologi dapat meningkatkan produktivitas dalam pekerjaan yang pada akhirnya meningkatkan kesejahteraan seseorang.

Hal ini sesuai dengan hasil penelitian berdasarkan data karakteristik responden di dapatkan yang memiliki pendidikan terakhir Diploma III Keperawatan berjumlah 44 responden dan yang memiliki pendidikan terakhir profesi Ners yakni 2 responden, serta pengalaman bekerja dari 46 responden yakni $\geq 5$ tahun sebanyak 31 responden $(67,39$ persen) serta yang memiliki pengalaman 3-4 tahun sejumlah 12 responden $(26,09$ persen), dan $\leq 2$ tahun sejumlah 3 reponden (6,52 persen).

Pengalaman adalah suatu kejadian yang pernah dialami seseorang dalam berinteraksi dengan lingkungannya. Ada kecenderungan pengalaman yang baik akan menimbulkan kesan yang membekas dalam emosi sehingga menimbulkan sikap posistif (Mangkunegara, 2007).

Faktor kemampuan pegawai (ability) secara psikologis terdiri dari kemampuan potensi (IQ) dan kemampuan realita (pendidikan). Oleh karena itu, pegawai perlu ditempatkan pada pekerjaan yang sesuai dengan keahliannya. Sementara itu, faktor motivasi terbentuk dari sikap (attitude) seorang pegawai dalam menghadapi situasi (situation) kerja. Motivasi merupakan kondisi yang menggerakkan diri pegawai terarah untuk mencapai tujuan kerja. Tinggi rendahnya kinerja seseorang tergantung pada faktor yang memengaruhinya yaitu faktor kemampuan dan faktor motivasi (Suarli, dkk., 2010).

Menurut analisis peneliti, berdasarkan kutipan teori-teori tersebut ada keselarasannya dengan hasil penelitian bahwa sebagian besar perawat mempunyai tindakan yang baik atau sesuai prosedur dalam pemberian kemoterapi yang didasari oleh pendidikan, pengetahuan, teknologi, serta kemampuan dan motivasi yang tinggi dalam melaksanakan tugasnya menjadi faktor untuk mencapai potensi kerja secara maksimal.

\section{c. Hubungan Tingkat Pengetahuan Perawat tentang Kemoterapi dengan Tindakan Pemberian Kemoterapi di RS Paru Dr.M. Goenawan Cisarua Bogor}

Hasil analisis bivariat dengan uji chi square dari 46 responden, diketahui yang memiliki pengetahuan baik tentang kemoterapi berjumlah 38 (82,6 persen) responden dengan tindakan pemberian kemoterapi sesuai prosedur sebanyak 26 responden (56,6 persen). Diperoleh nilai $p$ value $=0,001$ dengan nilai signifikan adalah $<0,05$. Hal ini berarti Ha diterima, secara statistik dapat disimpulkan ada hubungan bermakna antara tingkat pengetahuan perawat tentang kemoterapi dengan tindakan pemberian kemoterapi pada pasien kanker paru di RS Paru DR.M. Goenawan Partowidigdo Cisarua Bogor,

Pada penelitan yang dilakukan oleh Hidayati (2014) yang berjudul "Hubungan Tingkat Pengetahuan Perawat tentang Kemoterapi dengan Tindakan Pemberian Kemoterapi pada Pasien Kanker Payudara di RSUD Arifin Achmad Pekanbaru", dari 51 responden, yang memperlihatkan memiliki tingkat pengetahuan tinggi, mempunyai tindakan yang sesuai standar dalam pemberian kemoterapi pada kanker payudara berjumlah 27 orang (77,1 persen), dan yang memperlihatkan pengetahuan sedang, mempunyai tindakan yang sesuai dengan standar yaitu 8 orang (57,1 persen), dan responden yang memilki tingkat pengetahuan kurang mempunyai tindakan yang sesuai dengan standar berjumlah 0 orang (0 persen). Uji statistik uji chi square 
menunjukkan $p$ value sebesar 0,041 dimana $p$ value $\leq \alpha(0,05)$ dinyatakan Ha diterima.

Hasil penelitian ini sesuai dengan pernyataan Notoatmodjo (2007) bahwa seseorang yang mempunyai pengetahuan tentang kesehatan akan menjadi tahu dan mampu dalam mengatasi masalah kesehatan. Hal ini berarti jika seseorang tahu tentang kemoterapi akan mengetahui cara penanganan serta mampu melakukan tindakan pemberian kemoterapi pada pasien kanker paru. Pengetahuan dipengaruhi oleh beberapa faktor, yakni pendidikan, pengalaman, usia, minat, dan informasi serta pekerjaan.

Hasil penelitian menunjukkan sebagian besar responden memiliki pendidikan terakhir Diploma III Keperawatan, dan pengalaman bekerja rata-rata $\geq 5$ tahun dengan usia produktivitas interval 20-40 tahun.

Pendidikan memberikan pengetahuan bukan saja yang langsung dengan pelaksanaantugas, tetapijugalandasanuntuk mengembangkan diri serta kemampuan. Semakin tinggi pendidikan semakin tinggi, produktivitas kerja (Samsudin, 2005). Umur pada aspek psikologis dan mental membuat cara berpikir seseorang semakin matang dan dewasa (Hidayat, 2009).

Analisis peneliti ada yang bisa menjadikan keselarasan antara teori dan hasil berdasarkan data karakteristik responden didapatkan yang memiliki pendidikan terakhir diploma keperawatan berjumlah 44 responden dan yang memiliki pendidikan terakhir profesi ners yakni 2 responden. Kesimpulannya yakni seseorang yang mempunyai tingkat pengetahuan, pengalaman kerja yang banyak, serta diikuti bertambahnya usia akan memberikan pelayanan/perawatan dalam pemberian kemoterapi yang lebih baik hasilnya.

\section{SIMPULAN}

Simpulan penelitian ini ialah tingkat pengetahuan perawat tentang kemoterapi sebanyak 38 responden (82,6 persen) dalam kategori baik, sebagian besar responden dalam pelaksanaan tindakan pemberian kemoterapi sesuai prosedur yakni 31 responden (67,4 persen), dan ada hubungan antara tingkat pengetahuan perawat tentang Kemoterapi dengan tindakan pemberian kemoterapi pada pasien kanker paru dengan nilai $p$-value $=0.001$. Diharapkan pihak pengembangan SDM (Sumber Daya Manusia) RS. Paru DR. M. Goenawan Cisarua Bogor mengadakan pelatihan atau workshop mengenai kemoterapi agar dapat meningkatkan pengetahuan dan kinerja perawat untuk lebih baik lagi. Perawat disarankan untuk memakai APD (Alat Pelindung Diri) dengan baik dan benar untuk keselamatan dalam bekerja khususnya dalam tindakan pemberian kemoterapi.

\section{DAFTAR PUSTAKA}

Arikunto, S. 2006. Prosedur Penelitian Suatu Pendekatan Praktik. Rineka Cipta, Jakarta.

Boucher, J., Lucca, J., Hooper, C., Pedulla, L., dan Berry, D.L. 2015. "A Structured Nursing Intervention to Address Oral Chemotherapy Adherence in Patients With Non-Small Cell Lung Cancer. Vol. 4 number 42, Juli 2015". Diambil dari: https://www.ncbi.nlm.nih.gov/ pubmed/26148317. Diakses tanggal 4 Juli 2015.

Dempsey, J. 2008. "For Chemotherapy Administration". Critical Care Nursing Journal. Volume 63 number 1, Januari 2008. Diambil dari: http://onlinelibrary. wile y.com/doi/10.1002/1097 0142(19890101) 63:1\%3C37::AIDN 
CR2820630106\%3E3. 0.CO;2-Z/full. Diakses tanggal 4 Juli 2015.

Desen, W. 2008. Buku Ajar Onkologi Klinis. Jakarta: FK.

Hidayat, A.A. 2009. Metode Penelitian Keperawatan dan Teknik Analisis Data. Edisi Pertama. Jakarta: Salemba Medika.

Hidayati, S. 2014. "Hubungan Tingkat Pengetahuan Perawat tentang Kemoterapi dengan Tindakan Pemberian Kemoterapi pada Pasien Kanker Payudara di RSUD Arifin Achmad Pekanbaru". Skripsi. http://repository. unand.ac.id/17532/. Diakses tanggal 25 Agustus 2015.

Jayanti, E. 2013. "Evaluasi Penggunaan Kemoterapi pada Pasien Kanker Paru di Instalasi Rawat Inap RS "X". Naskah Publikasi. Diambil dari: http:// eprints.ums.ac.id/22771/9/NASKAH_ PUBLIKASI.pdf. (22 Februari 2016).

Karen, V., Coelho, J.C., Capelozzi, V.L., dan Azevedo, S.J. 2014. "Lung cancer in Brazil: Epidemiology and Treatment Challenges". Vol. 7, Number 14, November 2014. Diambil dari: https:// www.ncbi.nlm.nih.gov/pmc/articles/ PMC5310703/. Diakses tanggal 20 Desember 2014.

Mangkunegara, A.P.2007. Manajemen SDM. Remaja Rosdakarya, Bandung.

Notoatmodjo, S. 2007. Promosi kesehatan dan ilmu perilaku. Jakarta: Rineka Cipta.

Nursalam, P. 2009. Metodologi Riset Keperawatan. Jakarta: Sagung Seto.

Pinheiro, L.C., Zagar, T.M., Reeve, B.B. 2015. "The Prognostic Value of PreDiagnosis Health-Related Quality of Life on Survival: A Prospective Cohort Study of Older Americans with Lung Cancer". Vol. 4 number 14, Februari 2015. Diambil dari: https://www.ncbi.nlm.nih.gov/ pubmed/28194618. Diakses tanggal 4 Juli 2015.

RSPG. 2015. Standar Operasional Kemoterapi Pada Kanker Paru. Bogor: RSPG Cisarua.

Samsudin, S. 2005. Manajemen Sumber Daya Manusia. Pustaka Setia, Bandung.

Somantri, I, 2008, Asuhan Keperawatan pada Pasien dengan Gangguan Sistem Pernafasan. Salemba Medika, Jakarta.

Suarli, dkk. 2010. Manajemen dengan Pendekatan Praktis. Erlangga, Jakarta.

Tjay, T.H., dan Rahardja K., 2002, Obatobat Penting Khasiat, Penggunaan, dan Efek Sampingnya. PT Elek, Media Komputindo Jakarta.

WHO, 2007. The world health report 2007: a safer future: global public health security in the 21st century. Switzerland: WHO Press. Diambil dari: www.who. int/whr/2007/whr07_en.pdf. Diakses tanggal 4 Juli 2015.

Wong, J.Y., Bassig, B.A., Seow, W.J., Silverman, D.T., Lan, Q. 2015. "Lung Cancer Risk in Welders and Foundry Workers with A History of Heavy Smoking in the USA: The National Lung Screening Trial". Vol. 8 Number 9, Januari 2015. Diambil dari: https://www.ncbi.nlm. nih.gov/pubmed/28069970. Diakses tanggal 4 Juli 2015.

Yanase, K., Funaguchi, N., Hirotoshi, L., dan Minatoguchi, S. 2014. "Prevention of Radiation Esophagitis by Polaprezinc (Zinc L-carnosine) in Patients with Nonsmall Cell Lung Cancer who Received Chemoradiotherapy". Vol. 9 Number 15, September 2014. Diambil dari: https:// www.ncbi.nlm.nih.gov/pmc/articles/ PMC4659025/. Diakses tanggal 4 Juli 2015. 